\title{
Kierunki rozwiązań prawnych dotyczących zmian konstrukcji indywidualnego wskaźnika zadłużenia jednostek samorządu terytorialnego
}

\author{
Directions of legal solutions concerning changes \\ in the structure of individual debt ratios of local \\ authority units
}

Streszczenie. Celem opracowania jest omówienie charakteru prawnego długu jednostek samorządu terytorialnego oraz analiza konstrukcji prawnej indywidualnego wskaźnika zadłużenia tych jednostek. Głównym celem ustawowych limitów zadłużenia jest zahamowanie nadmiernego zadłużenia. Wspomniany wskaźnik powinien także umożliwić samorządom rozwój gospodarczy. Doktryna od dawna postuluje wprowadzenie zmian w konstrukcji indywidualnego wskaźnika zadłużenia. W Ministerstwie Finansów trwają prace, które umożliwią dokonanie restrukturyzacji i wcześniejszej spłaty długu. Inne proponowane zmiany mające na celu zwiększenie bezpieczeństwa finansowego samorządów terytorialnych mogą wpłynąć na obniżenie ich zdolności kredytowej i potencjału inwestycyjnego. 
Alicja Młynarczyk

Artykuł omawia kwestie związane z ustaleniem optymalnego charakteru prawnego indywidualnego wskaźnika zadłużenia.

Słowa kluczowe: charakter prawny długu jednostek samorządu terytorialnego; restrukturyzacja długu samorządów terytorialnych; modyfikacja konstrukcji indywidualnego wskaźnika zadłużenia; zwiększenie bezpieczeństwa finansowego samorządów terytorialnych.

Abstract. This paper aims at presenting the legal status of debts of local authorities and analysing the legal structure of individual debt ratios of such units. Limits of the statutory indebtedness aims mainly at to hindering going into excessive debts. The ratio mentioned above should also foster economic development of local authorities. For a long time, the doctrine has been calling for an introduction of certain changes in a structure of an individual debt ratio. The Ministry of Finances performs works to make it possible to restructure and repay debts earlier. Other intended changes are designed to increase financial security of territorial self-governments, what may result in lowering their creditworthiness and investment potential. This paper discusses issues related to finding an optimal legal character of the individual debt ratios.

Keywords: legal character of a debt of territorial self-government units; restructuring of debts of local authority units; modification of the structure of the individual debt ratio; increase of financial security of the territorial self-governments.

\section{Wstęp}

Celem opracowania jest analiza proponowanych kierunków rozwiązań prawnych dotyczących konstrukcji indywidualnego wskaźnika zadłużenia. W naukach ekonomicznych i z zakresu prawa finansowego formułowane są kryteria, na podstawie których powinien on zostać unormowany, aby umożliwił samorządom w sposób optymalny zarządzanie finansami. Indywidualny wskaźnik zadłużenia powinien zapewnić samorządom rozwój gospodarczy, gwarantować realizację inwestycji, a także musi być przejrzysty i dostosowany do wdrażanej strategii finansowej. Zahamowanie nadmiernego zadłużenia jednostek samorządu terytorialnego wydaje się kluczową kwestią, jaką należy brać pod uwagę w regulacjach prawnych 
odnoszących się do wspomnianej reguły fiskalnej. W celu ustalenia zobiektywizowanych kryteriów i konstrukcji indywidualnego wskaźnika zadłużenia omówienia wymaga charakter długu jednostek samorządu terytorialnego. Następnie należy dokonać oceny, w jakim zakresie ustalony w art. 243 ust. 1 ustawy o finansach publicznych indywidualny wskaźnik zadłużenia spełnia kryteria optymalnej reguły fiskalnej.

\section{Charakterystyka długu publicznego jednostek samorządu terytorialnego}

Ustawa o finansach publicznych reguluje formy prawne zaciągania długu publicznego przez jednostki samorządu terytorialnego (art. 89-93), ale nie definiuje pojęcia „dług samorządowy”. Także w przepisach konstytucyjnych odnoszących się do państwowego długu publicznego (art. 216 ust. 5) nie zostało ujęte pojęcie „dług samorządowy”. Dług publiczny, o którym mowa w art. 216 Konstytucji, jest nazwą zbiorczą i ogólną, złożoną z części zarówno rządowej, jak i samorządowej. W literaturze z zakresu prawa finansowego postuluje się ujęcie pojęcia „dług samorządowy” w ustawie o finansach publicznych, ponieważ w regulacjach prawnych innych krajów rozróżnia się dług państwowy i dług samorządowy ${ }^{1}$. W prawie unijnym stosowana jest kategoria długu instytucji rządowych i samorządowych ${ }^{2}$.

Doktryna, definiując termin „dług publiczny samorządu”, zwraca uwagę na jego umowny charakter ${ }^{3}$. Oceniając charakter prawny długu jednostek samorządu terytorialnego, zauważa się, że pojęcie to oznacza zbiorczą, ogólną kategorię opisującą działalność samorządu związaną z kredytami, pożyczkami, obligacjami i poręczeniami ${ }^{4}$. Analizując dług publiczny jednostek samorządu terytorialnego, stwierdza się, iż dług ten

C. Kosikowski, Ustawa o finansach publicznych, „Państwo i Prawo” 1999, nr 3, s. 11.

P. Zawadzka, Dług publiczny w sektorze finansów publicznych, [w:] R. Mastalski,

E. Fojcik-Mastalska (red.), Prawo finansowe, Warszawa 2011, s. 115.

A. Borodo, Polskie prawo finansowe zarys ogólny, Toruń 2010, s. 223.

A. Borodo, Kredyty, pożyczki i obligacje jako źródło finansowania zadań jednostek samorzqdu terytorialnego, [w:] A. Borodo (red.), Samorzq̨d terytorialny a banki, Toruń 2002 , s. 8. 
jest następstwem stosunku prawnego o złożonym charakterze, mającego swe źródło w umowach (np. umowie pożyczki), a także w ustawach określających formy działalności finansowej samorządu ${ }^{5}$. Niektórzy autorzy wyróżniają także kategorię długu lokalnego, rozumianego jako ogół zobowiązań gmin i powiatów, które będąc stroną właściwych umów, są zobligowane do zapłaty roszczeń z tytułu zaciągniętych kredytów i pożyczek wyemitowanych papierów wartościowych, przyjętych depozytów oraz zobowiązań wymagalnych ${ }^{6}$.

W ocenach długu sektora lokalnego wskazuje się jego prorozwojowy charakter ${ }^{7}$. Występowanie zadłużenia w budżetach samorządowych jest spowodowane przede wszystkim wykorzystywaniem deficytu jako instrumentu polityki inwestycyjnej. Doktryna prawa finansowego wyróżnia długi opłacalne i nieopłacalne. Za opłacalne uznaje te długi, które pozwalają finansować przedsięwzięcia inwestycyjne, które mogą być źródłem dodatkowych dochodów pozwalających na spłatę zadłużenia (rat i odsetek) $\mathrm{w}$ przyszłości ${ }^{8}$. Ustawa o finansach publicznych $\mathrm{z}$ dnia 27 sierpnia 2009 r. ${ }^{9}$, odnosząc się do długu publicznego jednostek samorządu terytorialnego, stwierdza, iż dług ten obejmuje zobowiązania z tytułu wyemitowanych papierów wartościowych opiewających na wierzytel-ności pieniężne, zaciągniętych kredytów i pożyczek, przyjętych depozy-tów, wymagalnych zobowiązań: a) wynikających z odrębnych ustaw oraz prawomocnych orzeczeń sądów lub ostatecznych decyzji administra-cyjnych, b) uznanych za bezsporne przez właściwą jednostkę sektora finansów publicznych będącą dłużnikiem. Wśród rodzajów kredytów i pożyczek, jakie mogą zaciągać jednostki samorządu

5 A. Borodo, Finanse publiczne Rzeczypospolitej Polskiej. Zagadnienia prawne, Bydgoszcz 2000, s. 257.

$6 \quad$ M. Zioło, Zadłużenie gmin - przesłanka czy ograniczenie $w$ procesie kreowania ich rozwoju? Analiza przypadku na przykładzie gmin województwa zachodniopomorskiego, [w:] J. Szołno-Koguc, A. Pomorska (red.), Ekonomiczne i prawne uwarunkowania i bariery redukcji deficytu i długu publicznego, Warszawa 2017, s. 474.

7 M. Poniatowicz, Dobry dług versus zły dług, czyli o specyfice zadłużenia sektora samorzq̨dowego, [w:] J. Szołno-Koguc, A. Pomorska (red.), Ekonomiczne..., s. 489.

A. Borodo, Samorzq̨d terytorialny system prawnofinansowy, Warszawa 2006, s. 218.

9 Ustawa o finansach publicznych z dnia 27 sierpnia 2009 r. (tekst jedn. Dz.U z 2017 r., poz. 2077 ze zm.). 
terytorialnego, można wyszczególnić długoterminowe zobowiązania przeznaczone na cele inwestycyjne. Powstające $\mathrm{z}$ tego tytułu zadłużenie można zaliczyć do długów opłacalnych.

Rozpatrując prawną instytucję długu publicznego, doktryna uznaje za istotny zakres i sposób jego determinacji prawnej. Na podstawie analizy art. 73 ust. 3 u.f.p. stwierdza się, że w ujęciu prawnym dług publiczny, a więc i jednostek samorządu terytorialnego, nie obejmuje pełnej wartości wszystkich zobowiązań jednostek sektora finansów publicznych. Nie zalicza się do niego wzajemnego zadłużenia jednostek sektora finansów publicznych oraz wszystkich dodatkowych wartości zobowiązań zwiększających ich wartość nominalną. Wyrażany jest więc pogląd, zgodnie z którym zakres prawnego pojęcia długu publicznego jest węższy niż ujęcia ekonomicznego ${ }^{10}$. Jednocześnie zaleca się rozpatrywanie zagadnień prawnych długu jednostek samorządu terytorialnego w aspekcie zasady równowagi budżetowej, która co prawda dopuszcza do uchwalenia deficytu budżetowego, ale wymaga wskazania źródeł jego sfinansowania ${ }^{11}$. Ponadto do polskiego systemu finansów samorządowych wprowadzona została tzw. złota reguła zrównoważonego budżetu. Jest ona realizowana poprzez wydzielenie budżetu bieżącego (operacyjnego) oraz majątkowego (inwestycyjnego), przy czym możliwość finansowania deficytu przez instrumenty dłużne dopuszczana jest tylko w odniesieniu do budżetu majątkowego ${ }^{12}$. Art. 242 ustawy o finansach publicznych wprowadza ograniczenia w uchwalaniu budżetu jednostki samorządu terytorialnego w części bieżącej z deficytem. Jednak zdaniem doktryny nie jest to równoznaczne $\mathrm{z}$ zakazem finansowania wydatków bieżących środkami zwrotnymi. Słuszny wydaje się pogląd, według którego jednostki samorządu terytorialnego mogą od 2011 r. faktycznie finansować ze środków zwrotnych wydatki bieżące, niemniej kwota zaciągniętego długu

10 W. Miemiec, Kategoria kredytu i pożyczki jako tytułów zaliczanych do państwowego długu publicznego $w$ ustawie o finansach publicznych $i \mathrm{w}$ rozporzqdzeniu wydanym na jego podstawie, [w:] J. Szołno-Koguc, A. Pomorska (red.), Ekonomiczne..., s. 183, 187.

11 J. Glumińska-Pawlic, Państwowy dług publiczny a rozwój gospodarki lokalnej, [w:] J. Szołno-Koguc, A. Pomorska (red.), Ekonomiczne..., s. 430.

12 E. Kornberger-Sokołowska, Finanse jednostek samorzqdu terytorialnego, Warszawa 2012, s. 199. 
nie może wynikać z niedoboru planowanych i posiadanych środków finansowych przeznaczonych na wydatki bieżące ${ }^{13}$.

Określenie bezpiecznych granic zadłużenia dla podmiotów publicznych i kontroli zobowiązań finansowych, które kreują dług, jest konieczne, bowiem negatywną cechą zbyt wysokiego długu publicznego jest zagrożenie dla wykonywania w przyszłości ustawowych zadań przez samorząd terytorialny. W tym celu można stosować zabezpieczenia ilościowe, takie jak dopuszczalny poziom zadłużenia, lub jakościowe wprowadzane w drodze odpowiednich regulacji publicznych ${ }^{14}$.

\section{Indywidualny wskaźnik zadłużenia jednostek samorządu terytorialnego - ogólna charakterystyka i próba oceny jego funkcjonowania}

Celem wprowadzenia indywidualnego wskaźnika zadłużenia było, zdaniem projektodawców obecnie obowiązujących rozwiązań prawnych, umożliwienie jednostkom samorządu terytorialnego o znacznym potencjale rozwojowym prowadzenia bezpiecznej polityki rozwojowej. Zakładano zwiększenie ostrożności przy zaciąganiu nowych kredytów i pożyczek przez te jednostki, których dochody są już w znacznym stopniu obciążone spłatami zobowiązań. W uzasadnieniu do ustawy o finansach publicznych z dnia 27 sierpnia 2009 r. przewidziano, że roczna wartość spłat zobowiązań i ich obsługi do planowanych dochodów nie może przekroczyć wskaźnika opartego na średniej arytmetycznej z obliczonych dla ostatnich trzech lat relacji dochodów bieżących, powiększonych o wpływy uzyskane ze sprzedaży majątku oraz pomniejszonych o wydatki bieżące do dochodów ogółem. Wskaźnik ten jest liczony na podstawie

13 J.M. Salachna, Zakres budżetu jednostki samorzqdu terytorialnego, [w:] E. Ruśkowski, J.M. Salachna (red.), Nowa ustawa o finansach publicznych wraz z ustawq wprowadzajq̨cq. Komentarz praktyczny, Gdańsk 2010, s. 777.

14 K. Sawicka, Dług jednostek samorzqdu terytorialnego jako przedmiot kontroli regionalnych izb obrachunkowych, [w:] J. Szołno-Koguc, A. Pomorska (red.), Ekonomiczne..., s. 535. 
wielkości wynikających ze sprawozdań z trzech ostatnich lat i przedstawia rzeczywiste możliwości danej jednostki samorządu terytorialnego w zakresie spłaty zobowiązań. Jednocześnie zaproponowano, by w limicie spłaty zobowiązań uwzględnić kwotę przypadających w danym roku budżetowym spłat i wykupów zobowiązań związku współtworzonego przez daną jednostkę w wysokości proporcjonalnej do jej udziału we wspólnej inwestycji współfinansowanej kredytem, pożyczką lub emisją obligacji spłacanych lub wykupywanych w danym roku budżetowym. W pozostałych przypadkach w wysokości proporcjonalnej do udziału tejże jednostki we wpłatach wnoszonych na rzecz związku, którego jest członkiem. W drodze wyjątku projektodawcy omawianej konstrukcji indywidualnego wskaźnika zadłużenia zaproponowali wyłączenie wymienionych środków z ograniczeń limitujących spłatę zobowiązań w celu zwiększenia zdolności absorbcji środków unijnych i środków z pomocy udzielonej przez państwa należące do Europejskiego Stowarzyszenia Wolnego Handlu.

Oceniając wzór algorytmu zawartego w art. 243 ust. 1 ustawy o finansach publicznych, stwierdza się, że nie uwzględnia on kwoty nadwyżki z lat ubiegłych oraz wolnych środków, dlatego niezależnie od zachowania dopuszczalnej przez ustawodawcę równowagi w części bieżącej budżetu jednostki samorządu terytorialnego, wątpliwe będzie uzyskanie dodatniego wskaźnika warunkującego możliwość dokonywania spłat zobowiązań dłużnych (w tym odsetkami, dyskontem). Jednocześnie wskazywano na możliwość wystąpienia dodatniego wskaźnika średniej arytmetycznej z trzech lat poprzedzających rok budżetowy - w tych jednostkach, które będą pokrywać deficyt sekcji bieżącej budżetu nadwyżką z lat ubiegłych lub wolnymi środkami, o ile w tych latach jednostka samorządu terytorialnego uzyskiwała znaczące dochody ze sprzedaży majątku, gdyż powiększają one przy wyliczaniu wskaźnika kwoty dochodów bieżących ${ }^{15}$. Według innych opinii omawiany wskaźnik nie ma bardziej indywidualnego charakteru niż górna granica rocznego

15 J.M. Salachna, Nowe formy prawne ograniczania długu oraz zadłużenia samorzqdu terytorialnego - próba oceny, [w:] J. Szołno-Koguc, A. Pomorska (red.), Ekonomiczne..., s. 527. 
zadłużenia czy górna granica globalnego zadłużenia obowiązującego na mocy art. 169 i 170 ustawy o finansach publicznych z 2005 r., gdyż w zakresie wskaźnika i jego granic brane są pod uwagę te same wielkości spłat rat kredytów i pożyczek wraz z odsetkami, emitowanych papierów wartościowych, potencjalnych spłat kwot wynikających z udzielonych przez jednostkę samorządu terytorialnego poręczeń oraz gwarancji. Za istotną różnicę wskaźnika od górnej granicy globalnego zadłużenia uznano, brane pod uwagę przy jego obliczaniu wartości historyczne za ostatnie dwa lata budżetowe oraz wynikające ze sprawozdania za trzeci kwartał wykonywanego budżetu. Natomiast w zakresie górnej granicy globalnego zadłużenia pod uwagę brany był całkowity dług jednostki. Na tej podstawie wysuwany był wniosek, że analizowany wskaźnik odnosi się jedynie do części długu jednostki samorządu terytorialnego ${ }^{16}$.

Wskazywano także na pewne trudności w planowaniu płatności związanych z obsługą zadłużenia jednostek samorządu terytorialnego, które związane są z planowaniem poszczególnych kwot uwzględnianych we wskaźniku. W przypadku zobowiązań finansowych, których należności uboczne ustalane są w oparciu o zmienną stopę procentową, przyjęcia pewnych założeń wymaga przyszły poziom odpowiednich stóp procentowych. W odniesieniu do pieniężnych zobowiązań finansowych wyrażonych w walutach obcych konieczne jest przyjęcie pewnych założeń dotyczących kursu walutowego ${ }^{17}$. Według innych poglądów konstrukcja prawej strony wzoru ujętego $\mathrm{w}$ art. 243 ust. 1 ustawy o finansach publicznych jest wadliwa, ponieważ licznik wskaźnika zawiera pełne wydatki bieżące obejmujące również wydatki z tytułu obsługi zadłużenia oraz potencjalnych spłat kwot wynikających z udzielanych poręczeń i gwarancji przez jednostki samorządu terytorialnego. Ponadto wykazuje się, że wada konstrukcji wskaźnika polega na tym, że wyżej wymienione wydatki obniżają dochody bieżące we wskaźnikach jednorocznych, a te pomniejszone dochody łącznie z dochodami ze sprzedaży majątku określają

16 P. Klimek, Prawnofinansowe przesłanki długu publicznego w gminie - małym mieście, [w:] J. Szołno-Koguc, A. Pomorska (red.), Ekonomiczne..., s. 570.

17 M. Bitner, Prawne instrumenty ograniczania deficytu budżetowego i długu publicznego jednostek samorzq̨u terytorialnego, Warszawa 2016, s. 492. 
wielkość dopuszczalnych środków na spłatę wcześniej zaciągniętych zobowiązań oraz na obsługę długu i wydatki z tytułu poręczeń i gwarancji udzielonych przez jednostki samorządu terytorialnego. Powoduje to zaniżenie indywidualnego wskaźnika zadłużenia o kwotę wydatków dokonywanych w ciągu trzech lat ze wskazanych tytułów ${ }^{18}$. Zastrzeżenia niektórych autorów wzbudza też ujęcie w art. 243 ustawy o finansach publicznych jako czynników algorytmu kwot z jednorocznej sprzedaży majątku ${ }^{19}$. Dochody z tego źródła doraźnie zwiększają możliwe do spłaty zadłużenie danej jednostki samorządu terytorialnego i umożliwiają w ten sposób zwiększenie zadłużenia. Zwraca się też uwagę na możliwość dokonywania sprzedaży zwrotnej nieruchomości, co prowadzi do ukrywania rzeczywistej kondycji finansowej jednostek samorządu terytorialnego $^{20}$. W literaturze $\mathrm{z}$ zakresu prawa finansowego uzasadnia się, że sposób obliczania indywidualnego wskaźnika zadłużenia zachęca zarządzających jednostką samorządu terytorialnego do odkładania spłaty zobowiązań w dłuższym okresie. W tym celu stosowane są długoterminowe kredyty (droższe od kredytów krótkoterminowych) oraz wieloletnie karencje w spłacie rat kapitałowych. Z takich instrumentów finansowych mogą korzystać przede wszystkim miasta na prawach powiatu, a nie małe gminy. Do negatywnych cech konstrukcji indywidualnego wskaźnika zadłużenia zaliczono też utrudnienia w efektywnej rekonstrukcji długu ${ }^{21}$.

Konstrukcję prawną indywidualnego wskaźnika zadłużenia uważa się za nieskuteczne rozwiązanie prawne, gdyż nie pozwala ona samorządom mającym możliwości finansowe na wcześniejszą spłatę długu już istniejącego. Na skutek takiej sytuacji jednostka samorządu terytorialnego przeznacza środki na odsetki i prowizje od wydłużonych w czasie zobowiązań

18 E. Kuzyniak, Możliwość parametrycznego ograniczania poziomu zadłużenia jednostek samorzqdu terytorialnego, [w:] J. Gliniecka, A. Drywa, E. Juchniewicz, T. Sowiński (red.), Praktyczne i teoretyczne problemy prawa finansowego wobec wyzwań XXI wieku, Warszawa 2017, s. 177.

19 A. Kamiński, Realność parametrów finansowania i zadłużenia $w$ wieloletniej prognozie finansowej, „Finanse Komunalne” 2016, nr 11, s. 25.

20 J.M. Salachna, Czy prawna regulacja w zakresie wieloletniej prognozy finansowej ma sens?, „Finanse Komunalne” 2016, nr 11, s. 10.

21 M. Jastrzębska, Nadmierne zadłużanie się jednostek samorzq̨du terytorialnego - przyczyny, skutki, przeciwdziałania, „Finanse Komunalne” 2016, nr 6, s. 25. 
zamiast na realizację zadań ${ }^{22}$. Doktryna zwraca też uwagę na innego rodzaju trudności przy ustalaniu poziomu indywidualnego wskaźnika zadłużenia. Wynikają one z powodu konieczności uwzględniania należności ubocznych w postaci odsetek od kredytów krótkoterminowych przy sporządzaniu prognozy kształtowania się spłat zadłużenia. W przypadku zaciągania przez jednostkę samorządu terytorialnego kredytów w rachunku bieżącym tego rodzaju zobowiązania spłacane są zaraz po wpłynięciu środków finansowych na rachunek jednostki samorządu terytorialnego. Argumentuje się, ze odsetki od wspomnianych zobowiązań dłużnych można ustalić dopiero po wykorzystaniu kredytu. Dlatego dla jednostki samorządu terytorialnego może być trudne dokładne wyliczenie w danym roku budżetowym kwoty przypadającej do spłaty odsetek od planowanych kredytów krótkoterminowych ${ }^{23}$. Dodatkowe utrudnienie przy obliczaniu tejże kwoty powstaje wówczas, gdy tego rodzaju limity kredytowe są odnawialne. Należne odsetki można ustalić dopiero po „wykorzystaniu” kredytu. Także w przypadku zaciągania kredytów i pożyczek na sfinansowanie przejściowego deficytu pojawiają się problemy z określeniem, w jakim okresie w czasie roku budżetowego jednostka samorządu terytorialnego będzie korzystać ze zwrotnych form finansowania ${ }^{24}$.

\section{Propozycje rozwiązań prawnych dotyczących określania poziomu zadłużenia jednostek samorządu terytorialnego}

Projektowana przez Ministerstwo Finansów nowelizacja ustawy o finansach publicznych ma umożliwić dokonywanie restrukturyzacji i wcześniejszą spłatę długu jednostek samorządu terytorialnego. Zmiany w konstrukcji indywidualnego wskaźnika zadłużenia zakładał projekt

22 R.P. Krawczyk, Problem skuteczności rozwiq̨zań prawnych zapobiegających nadmiernemu zadłużaniu się samorzq̨du terytorialnego, „Finanse Komunalne” 2016, nr 12, s. 12.

23 J.M. Salachna, Uwarunkowania prawne zarzqdzania długiem, [w:] M. Poniatowicz, J.M. Salachna, D. Perło, Efektywne zarzq̨dzanie długiem w jednostkach samorzqdu terytorialnego, Warszawa 2010, s. 110.

24 J.M. Salachna, Komentarz do art. 243 ustawy o finansach publicznych, [w:] E. Ruśkowski, J.M. Salachna (red.), Nowa ustawa o finansach publicznych..., s. 782. 
z dnia 1 kwietnia 2017 r. $^{25} \mathrm{~W}$ uzasadnieniu do projektu stwierdza się, że obecnie art. 243 nie pozwala jednostkom samorządu terytorialnego niemającym nadwyżki w części bieżącej z trzech ostatnich lat na wcześniejszą spłatę zadłużenia. Samorząd może mieć jednak inne środki, które mógłby przeznaczyć na spłatę długów, np. ze zwrotu udzielonej pożyczki. Powyższe proponowane rozwiązania miałyby zastosowanie wyłącznie do wcześniejszej spłaty zadłużenia przypadającej w latach wykraczających poza rok budżetowy, na który uchwalono budżet, i tylko do spłaty następującej w roku budżetowym. Tego rodzaju konstrukcja prawna powiększy możliwości dokonywania wydatków jednostek samorządu terytorialnego.

Kolejny rodzaj zmian ujęty w analizowanym projekcie odnosi się do uelastycznienia gospodarki finansowej jednostek samorządu terytorialnego. Jednym z rozwiązań mających służyć temu celowi byłoby upoważnienie organu wykonawczego przez organ stanowiący do zmian limitów zobowiązań i wydatków na realizację przedsięwzięć w wieloletniej prognozie finansowej w ramach środków pochodzących z budżetu środków europejskich. Dotyczy to sytuacji związanej ze zmianami w realizacji przedsięwzięcia finansowanego z udziałem środków europejskich.

Inne unormowania wymienionego wyżej projektu zakładają możliwość upoważnienia organu wykonawczego samorządu do dokonywania zmian wynikających z uzyskiwania płatności z budżetu środków europejskich na potrzeby racjonalnego wykonywania budżetu w danym roku. Zakłada się, że wspomniane rozwiązania prawne zwiększą absorpcję środków UE.

Trzecią istotną kwestią poruszaną w omawianym projekcie są planowane zmiany w zakresie kontroli zadłużenia. Zdaniem Ministerstwa Finansów obowiązujące obecnie przepisy służące ograniczaniu i monitorowaniu poziomu zadłużenia jednostek samorządu terytorialnego nie zapobiegają nadmiernemu zadłużaniu się jednostek samorządu terytorialnego w przypadku wykorzystywania przez te jednostki niestandardowych instrumentów finansowania, które nie podlegają wyraźnym

25 Biuletyn Informacji Publicznej Rządowego Centrum Legislacji, Uzasadnienie do projektu ustawy o zmianie ustawy o finansach publicznych z dn. 11.04.2017 r., nr UD229. 
ograniczeniom ustawowym w odniesieniu do ich przeznaczenia, czy też uwzględniania limitów określanych wskaźnikiem spłaty zobowiązań przypadających na dany rok. Ministerstwo obawia się niekontrolowanego wzrostu zadłużenia samorządów z powodu nadmiernego wykorzystywania tychże instrumentów.

W omawianym projekcie Ministerstwo Finansów zakłada objęcie limitem spłaty wszystkich zobowiązań, które wywołują skutki ekonomiczne zbliżone do umowy pożyczki lub kredytu i wpływają na poziom długu publicznego, czyli również wynikające z umowy o partnerstwie publiczno-prywatnym, a także papiery wartościowe, których zbywalność jest ograniczona, umowy sprzedaży, w których cena jest płatna w ratach, umów leasingu zawartych z producentem lub finansującym, jak również umów nienazwanych o terminie zapłaty dłuższym niż rok związanych z finansowaniem usług, dostaw, robot budowlanych. Projektodawcy wspomnianych rozwiązań uważają, że nastąpiło znaczne ograniczenie możliwości limitowania poziomu zadłużenia ze względu na tworzenie nowych konstrukcji kreujących zobowiązania podobne do kredytu lub pożyczki. Powyższe zobowiązania są spłacane ze środków zaklasyfikowanych do wydatków i nie podlegają rygorom dotyczącym obliczania wskaźnika zadłużenia na mocy art. 243 ustawy o finansach publicznych. Odnosi się to do umów leasingu zwrotnego, umów restrukturyzacji zadłużenia, forfaitingu, umów nienazwanych o terminie zapłaty dłuższym niż rok związanych z finansowaniem usług, dostaw, robót budowlanych. Modyfikacji w związku z tym uległby art. 91 ust. 1 ustawy o finansach publicznych mówiący o tym, że suma zaciągniętych kredytów i pożyczek oraz zobowiązań z wyemitowanych papierów wartościowych nie może przekroczyć kwoty określonej w uchwale budżetowej jednostki samorządu terytorialnego. W nowym brzmieniu przepisu proponuje się objęcie takim samym ograniczeniem zobowiązań wynikających z niestandardowych instrumentów finansowych.

Zapobieganiu kumulowania się kosztów obsługi długu i zakazie kapitalizacji odsetek ma służyć wprowadzenie konieczności ponoszenia kosztów obsługi zobowiązań przynajmniej raz do roku. Inne planowane zmiany polegałyby na wyłączeniu wolnych środków z reguły dotyczącej 
zrównoważenia budżetu unormowanej w art. 242 ustawy o finansach publicznych. W założeniu tego rodzaju rozwiązanie prawne ma przeciwdziałać przypadkom zaciągania przez niektóre jednostki samorządu terytorialnego zbyt wysokich kredytów i pożyczek, aby wygenerować wolne środki $\mathrm{z}$ tego tytułu i spełnić ustawowy wymóg art. 243 ustawy o finansach publicznych. Natomiast w kwestii wyeliminowania dochodów ze sprzedaży majątku przy wyliczaniu indywidualnego wskaźnika zadłużenia Ministerstwo Finansów zgadza się z opiniami doktryny, że pozbywanie się majątku samorządowego w niektórych przypadkach może skłaniać jednostki samorządu terytorialnego do zawyżania prognoz w zakresie ich możliwości spłaty zadłużenia.

Optymalizację w ustalaniu indywidualnego wskaźnika zadłużenia ma zapewnić korekta ust. 2 art. 243, według której przy wyliczaniu jego poziomu należy uwzględniać wielkości wykonane wynikające ze sprawozdań rocznych, a nie wielkości planowane po trzecim kwartale roku poprzedzającego rok budżetowy.

Nadal trwają prace nad zmianą konstrukcji prawnej indywidualnego wskaźnika zadłużenia jednostek samorządu terytorialnego. Rada Legislacyjna, opiniując ${ }^{26}$ omawiany projekt, pozytywnie oceniła proponowaną zmianę w zakresie możliwości wcześniejszej spłaty długu tych jednostek. Zaznaczając, że w obowiązującym stanie prawnym jest wprawdzie możliwe pokrywanie deficytu samorządów z nadwyżki budżetowej z lat ubiegłych i wolnych środków na rachunku bieżącym ich budżetu, ale przy obliczaniu indywidualnego wskaźnika pomija się te wartości. Obecna regulacja, zdaniem Rady, powoduje konieczność przeznaczania środków publicznych na pokrycie kosztów za udostępnienie kapitałów obcych. W opinii Rady Legislacyjnej projektowane regulacje sprzyjają dokonaniu restrukturyzacji długu jednostek samorządu terytorialnego, jeżeli doprowadzi ona do obniżenia kosztów jego obsługi. Jednakże problematyczne może być ustalenie w dłuższej perspektywie czasu, czy rzeczywiście nastąpi obniżenie kosztów obsługi długu z uwagi na zmieniające się uwarunkowania ekonomiczne. Natomiast odnosząc się do kwestii kontroli

26 Opinia Rady Legislacyjnej z dnia 9 czerwca 2017 r. o projekcie ustawy o zmianie ustawy o finansach publicznych z dnia 11 kwietnia 2017 r., RL-0303-19/17. 
pozyskiwania przez jednostki samorządu terytorialnego alternatywnych źródeł finansowania gospodarki (takich jak np. leasing zwrotny czy forfaiting), Rada Legislacyjna uznała za właściwy kierunek proponowanych rozwiązań. Jednocześnie Rada zauważa, że pewne kontrowersje mogą wywoływać rozwiązania szczegółowe. Rada zaleca znowelizowanie art. 72 ustawy o finansach publicznych, aby wyeliminować rozbieżności miedzy ustawą a rozporządzeniem wykonawczym Ministra Finansów określającym klasyfikację tytułów dłużnych; a także odesłaniami w innych artykułach ustawy do art. 72 (np. art. 243 ust. 1 pkt. 1). Rada wskazuje też na konieczność wyraźnego uregulowania zagadnienia dotyczącego ujmowania w budżecie samorządowym oraz indywidualnym wskaźniku zadłużenia operacji związanych z tzw. rolowaniem długu w przypadkach, w których operacje finansowe dokonują się bezpośrednio między bankiem a wierzycielem danej jednostki samorządu i nie zostały odzwierciedlone w jej budżecie. Rada Legislacyjna zgodziła się z argumentacją projektodawcy na temat wyeliminowania ze wskaźnika wpływów ze sprzedaży majątku. Zwraca jednak uwagę, iż może to doprowadzić do obniżenia zdolności kredytowej danej jednostki i tym samym jej potencjału inwestycyjnego. Według Rady modyfikacja wzoru nie likwiduje innych mankamentów, np. ujmowania kosztów odsetkowych w kosztach obsługi długu (po lewej stronie wzoru) i w wydatkach bieżących (po prawej stronie wzoru), co może skutkować w niektórych przypadkach obniżeniem wskaźników zadłużenia.

\section{Uwagi końcowe}

Propozycje Ministerstwa Finansów dotyczące wprowadzenia możliwości restrukturyzacji zadłużenia i wcześniejszej spłaty długu jednostek samorządu terytorialnego należy oceniać pozytywnie. Korzystne dla gospodarki finansowej samorządów może być również wydłużenie okresu, który jest brany pod uwagę przy obliczaniu indywidualnego wskaźnika zadłużenia. Dłuższy, sześcio- lub siedmioletni okres jest bardziej miarodajny od krótszego okresu trzyletniego dla dokonania oceny stanu ich gospodarki budżetowej. Na obniżenie poziomu zadłużenia w sposób istotny wpły- 
nie uwzględnianie przy wyliczaniu indywidualnego wskaźnika zadłużenia tzw. instrumentów niestandardowych. Chociaż tego rodzaju rozwiązanie prawne ograniczy w pewnym stopniu samodzielność finansową samorządów w pozyskiwaniu środków. Uzasadniona jest prawna ochrona jednostek samorządu terytorialnego przed upadłością, ze względu na wykonywanie przez samorząd zadań publicznych. Ustawowy limit zadłużenia nie powinien jednak oddziaływać hamująco na działania podejmowane przez samorząd terytorialny na rzecz pobudzania wzrostu gospodarczego. Indywidualny wskaźnik zadłużenia powinien w sposób optymalny łączyć ograniczenie nadmiernego zadłużenia jednostek samorządu terytorialnego z celami realizowanej przez nie polityki gospodarczej i założeniami zawartymi w wieloletnie prognozie finansowej.

\section{Bibliografia:}

Bitner M., Prawne instrumenty ograniczania deficytu budżetowego i długu publicznego jednostek samorzqdu terytorialnego, Wolters Kluwer, Warszawa 2016.

Borodo A., Finanse publiczne Rzeczypospolitej Polskiej. Zagadnienia prawne, Branta, Bydgoszcz 2000.

Borodo A., Kredyty, pożyczki i obligacje jako źródło finansowania zadań jednostek samorzqdu terytorialnego, [w:] A. Borodo (red.), Samorzq̨d terytorialny a banki, TNOiK, Toruń, 2002.

Borodo A., Samorzqd terytorialny. System prawnofinansowy, LexisNexis, Warszawa 2006.

Borodo A., Polskie prawo finansowe. Zarys ogólny, TNOiK, Toruń 2010.

Glumińska-Pawlic J., Państwowy dług publiczny a rozwój gospodarki lokalnej, [w:] J. Szołno-Koguc, A. Pomorska (red.), Ekonomiczne i prawne uwarunkowania i bariery redukcji deficytu i długu publicznego, Lex a Wolters Kluwer business, Warszawa 2017.

Jastrzębska M., Nadmierne zadłużanie się jednostek samorzq̨du terytorialnego - przyczyny, skutki, przeciwdziałania, „Finanse Komunalne” 2016, nr 6, s. $15-29$.

Kamiński A., Realność parametrów finansowania i zadłużania $w$ wieloletniej prognozie finansowej, „Finanse Komunalne” 2016, nr 11, s. 23-28.

Klimek P., Prawnofinansowe przesłanki długu publicznego w gminie - małym 
mieście, [w:] J. Szołno-Koguc, A. Pomorska (red.), Ekonomiczne i prawne uwarunkowania i bariery redukcji deficytu i długu publicznego, Lex a Wolters Kluwer business, Warszawa 2017.

Kornberger-Sokołowska E., Finanse jednostek samorzqdu terytorialnego, Lexis Nexis Polska, Warszawa 2012.

Kosikowski C., Ustawa o finansach publicznych, „Państwo i Prawo”, 1999, nr 3, s. 3-19.

Krawczyk R.P., Problem skuteczności rozwiqzań prawnych zapobiegajq̨cych nadmiernemu zadłużaniu się samorząów terytorialnych, „Finanse Komunalne” 2016, nr 12, s. 5-19.

Kuzyniak E., Możliwość parametrycznego ograniczania poziomu zadłużenia jednostek samorzqdu terytorialnego, [w:] A. Gliniecka, A. Drywa, E. Juchniewicz, T. Sowiński (red.), Praktyczne i teoretyczne problemy prawa finansowego wobec wyzwań XXI wieku, CeDeWu, Warszawa 2017.

Miemiec W., Kategoria kredytu i pozyczki jako tytułów zaliczanych do państwowego długu publicznego $w$ ustawie o finansach publicznych i rozporzqdzeniu wydanym na jego podstawie, [w:] J. Szołno-Koguc, A. Pomorska (red.), Ekonomiczne i prawne uwarunkowania i bariery redukcji deficytu i długu publicznego, Lex a Wolters Kluwer business, Warszawa 2017.

Poniatowicz M., Dobry dług versus zły dlug, czyli o specyfice zadłużenia sektora samorzqdowego, [w:] J. Szołno-Koguc, A. Pomorska (red.), Ekonomiczne i prawne uwarunkowania i bariery redukcji deficytu i długu publicznego, Lex a Wolters Kluwer business, Warszawa 2017.

Salachna J.M., Uwarunkowania prawne zarzqdzania długiem, [w:] M. Poniatowicz, J.M. Salachna, D. Perło, Efektywne zarzqdzanie długiem $w$ jednostkach samorzqdu terytorialnego, Oficyna a Wolters Kluwer business, Warszawa 2010.

Salachna J.M., Komentarz do art. 243 ustawy o finansach pulicznych, [w:] E. Ruśkowski, J.M. Salachna (red.), Nowa ustawa o finanasach publicznych wraz z ustawq wprowadzajq̨cq. Komentarz praktyczny, ODDK, Gdańsk 2010.

Salachna J.M., Czy prawna regulacja w zakresie wieloletniej prognozy finansowej ma sens? „Finanse Komunalne” 2016, nr 11, s. 5-12.

Salachna J.M., Nowe formy prawne ograniczania długu i zadłużenia samorzqdu terytorialnego - próba oceny, [w:] J. Szołno-Koguc, A. Pomorska (red.), Ekonomiczne i prawne uwarunkowania i bariery redukcji deficytu i długu publicznego, Lex a Wolters Kluwer business, Warszawa 2017. 
Sawicka K., Dług jednostek samorzqdu terytorialnego jako przedmiot kontroli regionalnych izb obrachunkowych, [w:] J. Szołno-Koguc, A. Pomorska (red.), Ekonomiczne i prawne uwarunkowania i bariery redukcji deficytu i długu publicznego, Lex a Wolters Kluwer business, Warszawa 2017.

Zawadzka P., Dług publiczny w sektorze finansów publicznych, [w:] R. Mastalski, E. Fojcik-Mastalska (red.), Prawo finansowe, Lex a Wolters Kluwer business, Warszawa 2011.

Zioło M., Zadłużenie gmin - przesłanka czy ograniczenie w procesie kreowania ich rozwoju? Analiza przypadku na przykładzie gmin województwa zachodniopomorskiego, [w:] J. Szołno-Koguc, A. Pomorska (red.), Ekonomiczne i prawne uwarunkowania i bariery redukcji deficytu i długu publicznego, Lex a Wolters Kluwer business, Warszawa 2017. 